\title{
Spatio-temporal Distribution Pattern of Oyster Larvae in Guaratuba Bay, Paraná State - Brazil
}

\author{
Susete Wambier Christo ${ }^{1 *}$ \\ https://orcid.org/0000-0001-9191-4171
}

Augusto Luiz Ferreira Júnior ${ }^{2}$

https://orcid.org/0000-0001-9336-0782

\section{Theresinha Monteiro Absher ${ }^{3}$}

https://orcid.org/0000-0002-5203-2798

\section{Andrea Cancela da Cruz Kaled ${ }^{3}$ \\ https://orcid.org/0000-0003-1958-1557}

\begin{abstract}
1State University of Ponta Grossa, Department of General Biology, Laboratory of Zoology, Ponta Grossa, Paraná, Brazil; ${ }^{2}$ Federal University of São Carlos, Post-graduation Program of Evolutionary Genetics and Molecular Biology, São Carlos, São Paulo, Brazil; ${ }^{3}$ Federal University of Paraná, Center for Marine Studies, Laboratory of Marine Mollusks, Pontal do Sul, Pontal do Paraná, Paraná, Brazil.
\end{abstract}

Received: 2019.03.24; Accepted: 2020.12.16.

Editors-in-Chief: Paulo Vitor Farago

Associate Editors: Paulo Vitor Farago

*Correspondence: swchristo@hotmail.com; 55 (41) 99999-8000. (S.W.C.).

\section{HIGHLIGHTS}

- Crassostrea oysters larvae patterns in estuarine environments.

- Larvae distribution patterns in Guaratuba Bay (Paraná State - Brazil).

Abstract: Crassostrea oysters present planktonic/planktotrophic larval development. Thus, it is essential knowing larvae distribution patterns in estuarine environments presenting oyster farms and spat collection. The aim of the current research is to investigate the spatio-temporal distribution of oyster larvae in Guaratuba Bay (Paraná State - Brazil) based on monthly samplings conducted with a plankton net $(50 \mathrm{~cm}$ diameter and $225 \mu \mathrm{m}$ mesh size) from June 2003 to June 2004 in three different points (Point I - bay's entrance; Point II - cultivation park; Point III - median sector of the bay). Plankton samples were preserved in $4 \%$ buffered formaldehyde. They were concentrated and quantified in the laboratory. The total number of larvae in the sample from each net was counted and corrected to a standard larvae $/ \mathrm{m}^{3}$ collection tow. Data about sea water temperature, salinity, transparency and pluviosity were also collected. Based on results about the spatial distribution of larvae, mean density was $33.30 \pm 42.73 \mathrm{larvae} / \mathrm{m}^{3}$ in Point I; $17.84 \pm 16.88 \mathrm{larvae} / \mathrm{m}^{3}$ in Point II and $55.53 \pm 78.31$ larvae $/ \mathrm{m}^{3}$ in Point III, during the studied period. Spring and Summer were the seasons recording the most expressive mean number of larvae; the largest concentration of them was found in Point III, in the middle section of the bay.

Keywords: Planktonic; Crassostrea; native oysters; Ostreidae; estuary. 


\section{INTRODUCTION}

Oysters are broadcast spawners, i.e., male and female oysters release eggs and sperm into the water column where fertilization takes place. Fertilized eggs develop into planktonic planktotrophic larvae [1,2]. Larval-period duration in natural environments is mainly determined by water temperature and food availability [3]. However, factors such as salinity and water turbidity can affect larval dispersion [4,5]. Although larvae are able to horizontally and vertically move in the water column, aspects such as currents and tidal speed enable wider larval dispersion, mainly in horizontal position [6,7]. Vertical larval displacement depends on the larval stage, as well as on environmental factors such as water temperature and salinity $[8,9,12]$.

The retention of larvae from pelagic estuaries is also influenced by their active and passive transport $[10,11]$. Complex interactions between the larval swimming and the circulation characteristics of the environment have been suggested as retention mechanisms [9], while other studies suggest that the larvae can maintain their position in the estuary, regardless of environmental factors [12]. Oyster larvae are most abundant near the surface of the water during their early stages of development, but they move closer to the bottom when they reach the end of their pelagic stage, theoretically because they are looking for a substrate for fixation [5]. Some studies have also addressed the influence of luminosity on the distribution of oyster larvae [13].

Therefore, the incidence of larvae in the plankton can be influenced by a series of factors such as physical and chemical features of the environment, food availability, predation or diseases, currents, active transport and the availability of proper substrate for fixation [14]. Thus, it is essential investigating oyster larvae distribution in the water column in order to evaluate their possible dispersion mechanisms in estuaries. Allocation of seed collectors in areas with a greater amount of pediveliger larvae can enhance seed capture [15;27;29]. Studies have found a greater abundance of recruitment in the estuarine sector next to natural oyster banks [30].

Although in Guatatuba Bay there two species of oysters cultivated, C. rhizophorae and C. brasiliana ( $\sin =$ C. gasar) [16] were identified, most adults specimens intertidal correspond to $C$. rhizoporae, where $97 \%$ of the incidence was based on electrophoresis analyzes [16]. The aim of the present study was to investigate the spatiotemporal distribution of oyster larvae along a longitudinal axis of Guatatuba Bay and to relate the observed patterns to environmental variables (sea-water temperature, salinity, transparency and pluviosity).

\section{MATERIAL AND METHODS}

Guaratuba Bay is located on the coastal plain of Southern Brazil (Figure 1); it is divided in four crossestuary sections: bay mouth - T1, middle point - T2, Cubatão River mouth - T3, and São João River mouth - T4 [17]. The river basins contributing to the total runoff into Guaratuba bay cover a surface area of $1,724 \mathrm{~km}$ and have drainage density 1.87 rivers. $\mathrm{km}^{-1}$. In addition, they present dendritic drainage pattern and mean river runoff of at least $80 \mathrm{~m}^{-1} \mathrm{~s}^{-1}$; approximately $24 \%$ of this area $(12.13 \mathrm{~km})$ is composed of shallow waters or sand and muddy banks [17]. 


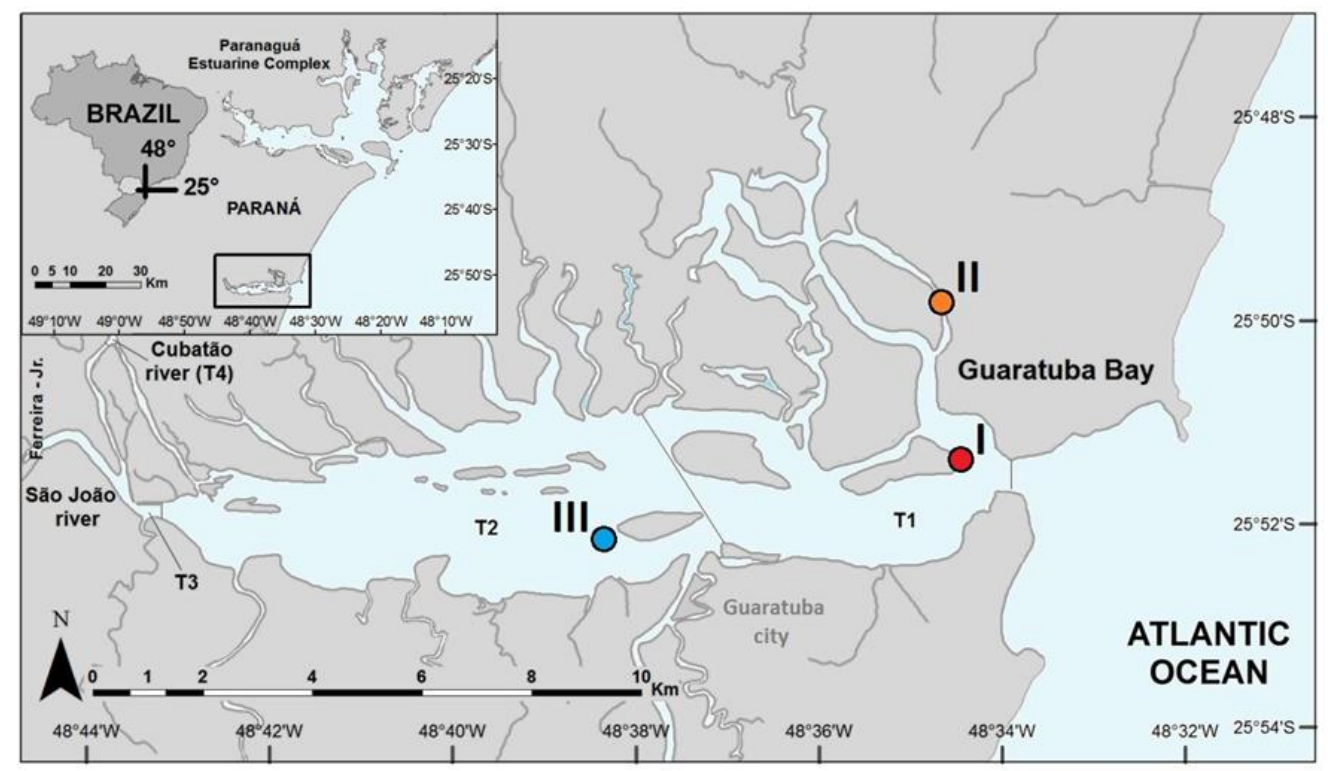

Figure 1. Location of points in Guaratuba Bay, Paraná - Brazil. Points: I (near Sepultura Island), II (oyster farms) and III (medium sector of the bay). Sections: T1 - bay mouth; T2 - middle; T3 - Cubatão river mouth; T4 - São João river mouth [17].

Monthly plankton samples were collected at three different locations in Guaratuba Bay: Point I - bay's

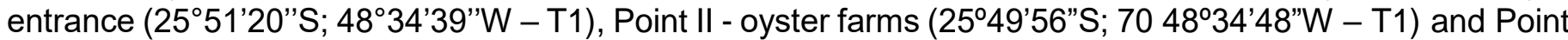

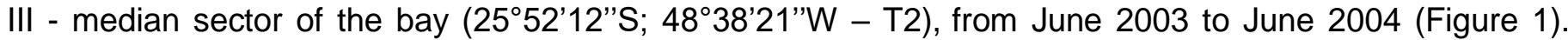
Samples were taken in two consecutive oblique drag (one-minute duration each) by using a conical plankton net $(50 \mathrm{~cm}$ diameter and $225 \square \mathrm{m}$ mesh size). Plankton samples were preserved in $4 \%$ buffered formaldehyde. Samples were concentrated in the laboratory and examined in a counting chamber, in stereomicroscope. The total number of pediveliger (height $>225 \mu \mathrm{m}$ ) in each net sample was counted and corrected to a standard larvae $/ \mathrm{m}^{3}$ collection tow. "D" larvae (beginning of larval development) were not characterized due to their size and difficult identification.

Data about seawater temperature, salinity, water transparency (Secchi Disk), and pluviosity were also collected monthly, parallel to plankton tows. Sea water temperature was measured with a mercury thermometer $\left(0.1^{\circ} \mathrm{C}\right.$ precision), salinity was measured with a portable refractometer (scale 1/100). Rainfall data were provided by the Technological Institute - SIMEPAR (Guaratuba Weather Station).

Larval density data were transformed into $\log (x+1)$. After data normality and homogeneity were evaluated, two Factoral ANOVAs were used to test significant differences $(a=0.05)$ in larval density (dependent variable) between independent variable (points and seasons; points and months) and Tukey test (post hoc). Principal Component Analysis (PCA) was conducted on a correlation matrix after the log 10 transformation of larval abundance data, which were associated with a set of environmental variables (seawater temperature, salinity, transparency and tidal phase) likely to influence larval abundance at the sampling stations in STATISCA 10 program.

\section{RESULTS}

\section{Environmental parameters}

Sea water temperature recorded annual variation $7^{\circ} \mathrm{C}$, since values oscillated between $20^{\circ} \mathrm{C}$ and $27^{\circ} \mathrm{C}$, as well as annual mean $24.0 \pm 2.2^{\circ} \mathrm{C}$ in Points I, II and III (Supplementary material FS1 and FS2). The highest temperatures were registered from October 2003 to March 2004 (Supplementary material FS1 and FS2). Mean annual salinity was $26.0 \pm 4.0$ in Point I (annual range 10); $23.5 \pm 2.0$ in Point II (annual range 6); and $18.5 \pm 3.4$ in Point III (annual range 13) (Supplementary material FS3 and FS4). The annual mean of Secchi depth (sea water transparency) was $1.5 \pm 0.4 \mathrm{~m}$ in Point I; $1.1 \pm 0.2 \mathrm{~m}$ in Point II; and $1.3 \pm 0.5 \mathrm{~m}$ in Point III. The highest sea water transparency value was found in June $2003(2.4 \mathrm{~m})$ and the lowest value $(0.50 \mathrm{~m})$ in February 2004, in Point III. Pluviosity data indicated higher rainfall rate in April $(283.2 \mathrm{~mm})$, which was followed by values recorded in January $(266.8 \mathrm{~mm})$, February $(257.8 \mathrm{~mm})$ and March $2004(255.2 \mathrm{~mm})$. Winter months recorded the lowest rainfall rate. 


\section{Spation-temporal distribution}

Analyses showed mean density $85.07 \pm 42.73$ larvae/ $\mathrm{m}^{3}$ in Point I; $36.83 \pm 40.27$ larvae $/ \mathrm{m}^{3}$ in Point II and $125.21 \pm 78.31$ larvae $/ \mathrm{m}^{3}$ in Point III, during the studied period. Analysis of variance showed significant differences $(p<0.01)$ in larval density between sampling points (Figure 2; Supplementary material TS1 and TS4).

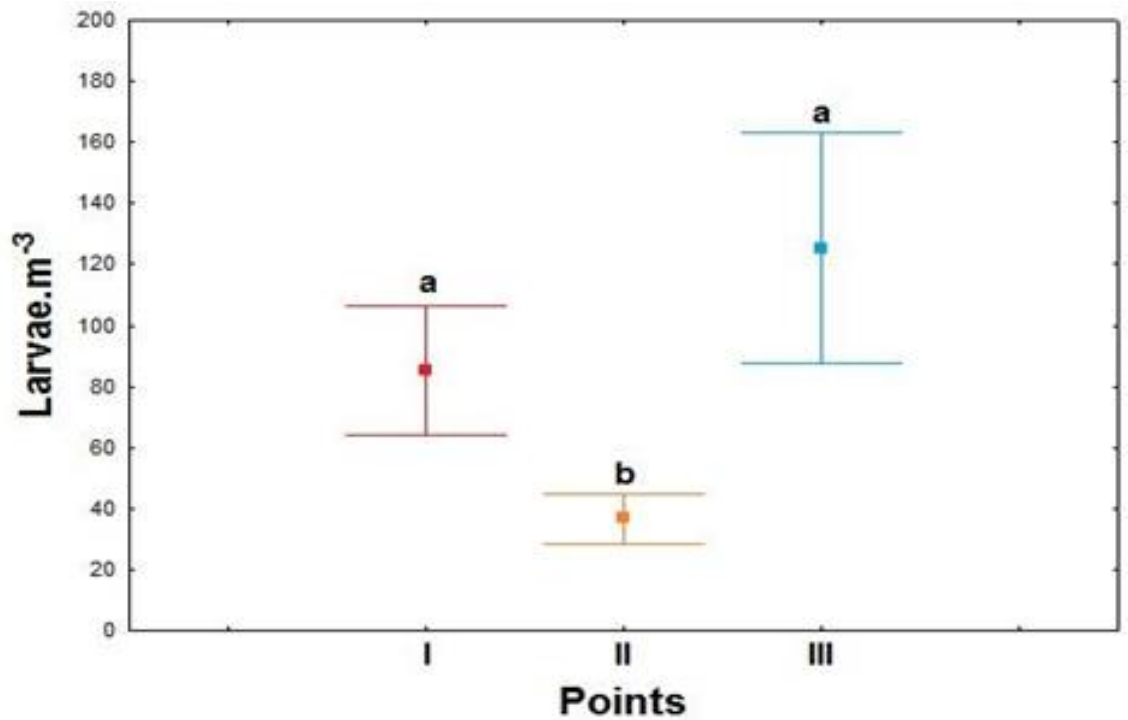

Figure 2. Space distribution of larvae. $\mathrm{m}^{-3}$ in the Ponts I, II and III during the studied period in Guaratuba Bay, Paraná - Brazil $(N=1,387)$. $\square$ : mean ( $n=24)$; I: stander deviation; letters indicate differences $(p<0.05)$.

The three herein studied points recorded significant larval mean $(<0.01)$ during spring, summer and autumn; however, this value decreased as winter approached (Figure 3; Supplementary material FS5; TS1 to TS3 and TS5).

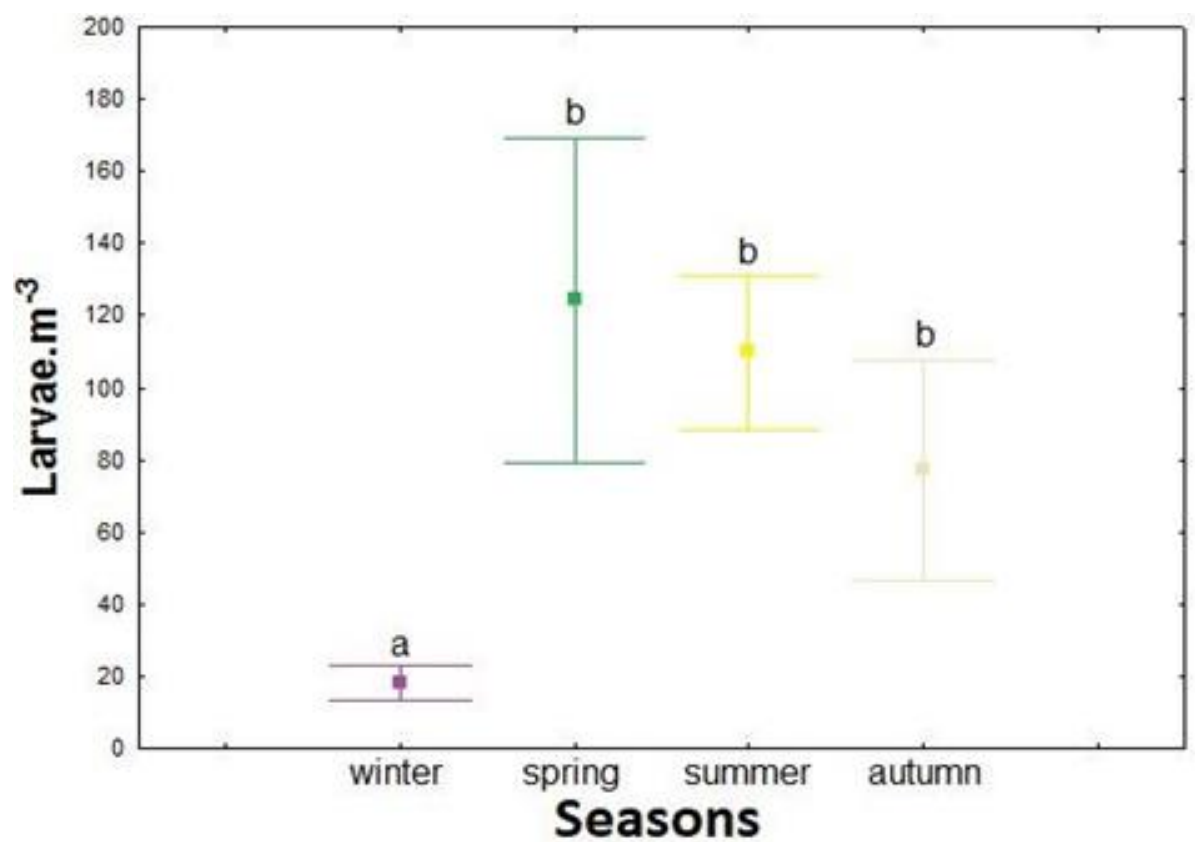

Figure 3. Seasonal averages of larvae. $m^{-3}$ in Guaratuba Bay, Paraná - Brazil. $\square$ : mean $(n=18)$; I: stander deviation; letters indicate differences $(p<0.05)$.

Plankton samples showed the incidence of oyster larvae throughout the sampling period; the greatest abundance was recorded between spring (November 2003) and autumn (March 2004) in the three studied points (Figure 4; Supplementary material FS5). Points I and II showed the highest density of larvae/ $\mathrm{m}^{3}$ in February, whereas Point III recorded it in March 2004 (Figure 4). There was significant difference $(p<0.01)$ 
between larval density and monthly sampling in points (Figure 4; Supplementary material FS5; TS1, TS3 and TS5).

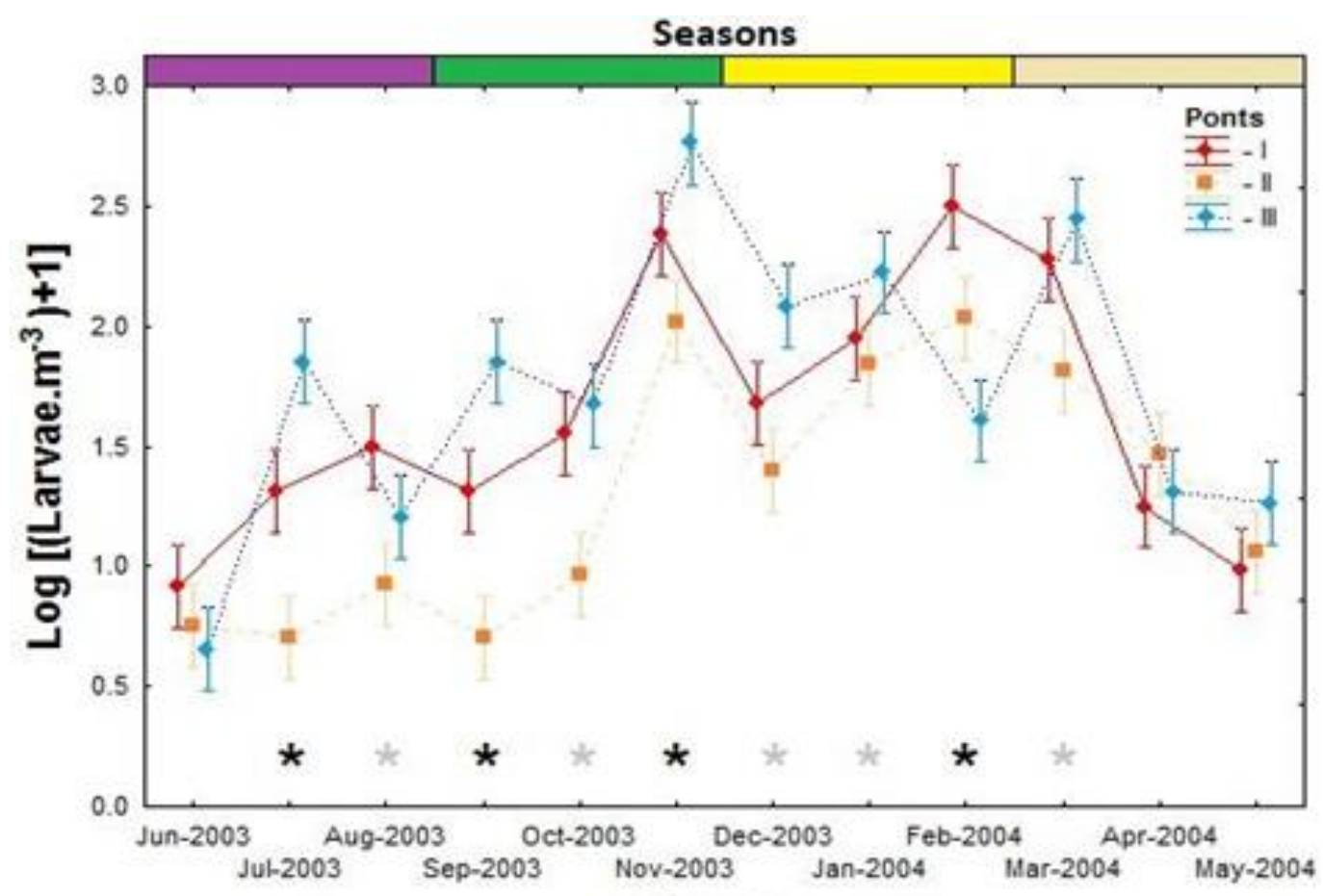

Months

Figure 4. Monthly averages of larvae. $\mathrm{m}^{-3}$ density in the Ponts I (red), II (orange) and III (blue) in Guaratuba Bay, Paraná - Brazil. $\square$ and $\bullet$ : mean ( $n=2)$; I: stander deviation; asterisk indicates differences $(p<0.05$; grey: $\neq 2$ points; black: $\neq 3$ points); winter (purple); spring (green); summer (yelow) and autumn (beige).

Points I and II recorded higher densities in summer (mean values $67.38 \mathrm{larvae} / \mathrm{m}^{3}$ and $33.74 \mathrm{larvae} / \mathrm{m}^{3}$, respectively), when seasonal densities were analyzed by using seasons as independent variables. Point III showed higher densities in spring (2003), when it recorded mean value 111.67 larvae $/ \mathrm{m}^{3}$ (Supplementary material FS5A).

\section{Environmental and biological interactions}

The largest larval density in Points I, II and III was associated with high temperature and rainfall rates in spring (2003) and summer (2003/2004), in less saline and less transparent waters. Larval density in Point III was strongly associed by temperature and pluviosity in summer (2003/2004), in low-salinity waters; whereas larvae incidence in Points I and II was less influenced by salinity (Figure 4 and 5; Supplementary material FS1 to FS5). 


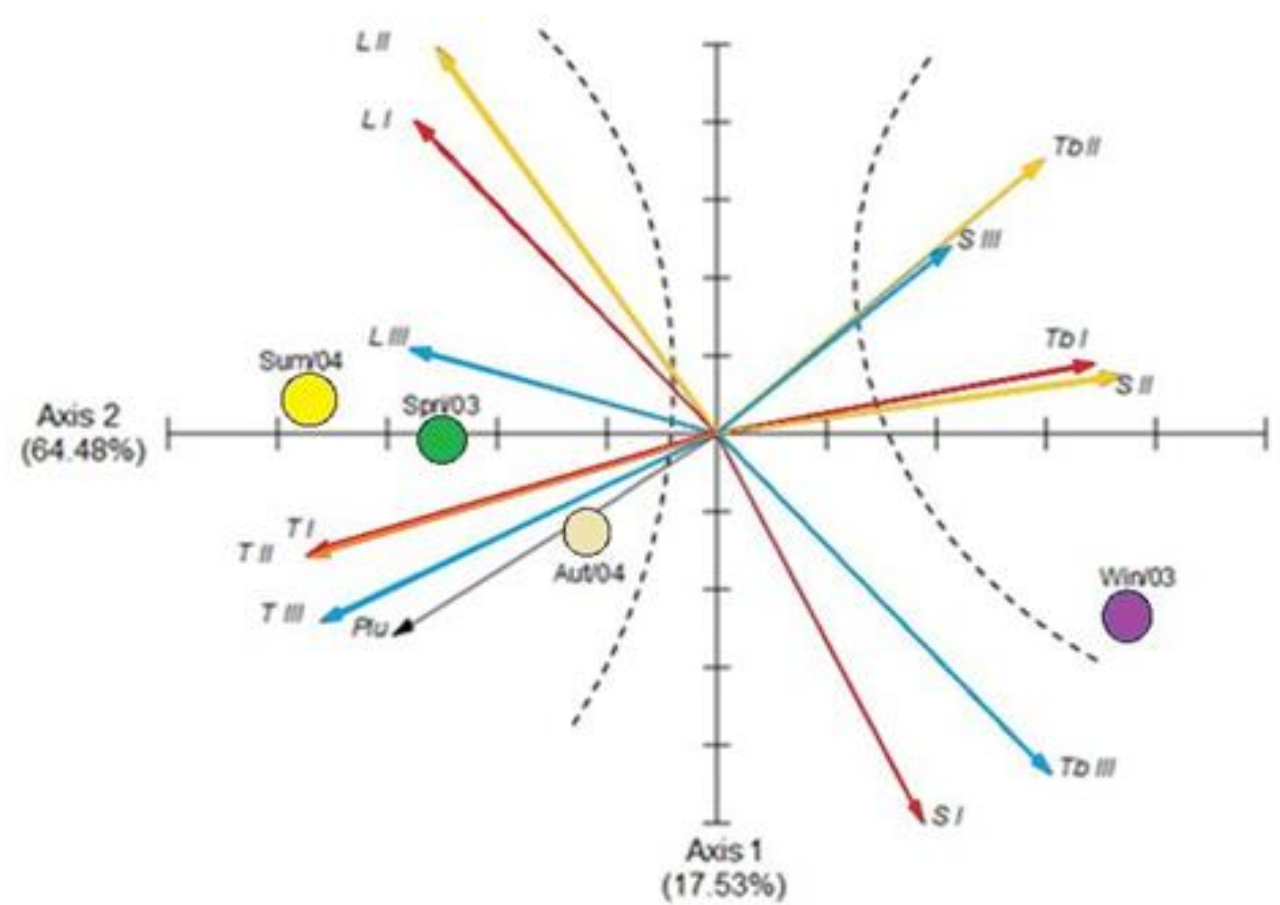

Figure 5. Principal Components Analysis in Points I, II and III, with the projection of the vector-variables, being: $\mathrm{L}=$ larvae. $\mathrm{m}^{-3} ; \mathrm{T}=$ temperature $\left({ }^{\circ} \mathrm{C}\right) ; \mathrm{S}=$ salinity; $\mathrm{Tb}=$ transparency of water $(\mathrm{m})$; Plu = pluviosity $(\mathrm{mm}) ;$ circles = Seasons $($ Sum $=$ summer; Aut $=$ autumn; Win $=$ winter; Spri $=$ spring $)$, with the seasonal observations in the factorial plan I - II. Seasonal mean values in the period sampled from June/03 to May/04.

\section{DISCUSSION}

Several stages compose oysters' reproductive cycle; they start at gametogenesis, pass through larval development until larvae reach settlement competence, settle and, finally, undergo metamorphosis. All these stages are influenced by endogenous and exogenous factors, such as temperature, food availability and salinity, which are the ones mostly influencing gonadal maturation and larval cycle duration $[18,9]$. Based on results in the present study, there are larvae in plankton throughout the year; however, this pattern is strongly influenced by temperature, since the highest larval density was observed under high temperatures and gonadal maturation $[19,5]$. The species $C$. rhizophorae and $C$. brasiliana ( $\sin =C$. gasar) recorded and 24-day pelagic larval duration under controlled laboratory conditions, respectively, instead of larval periods (at $27^{\circ} \mathrm{C}$ ) [20]. This outcome is similar to that found by [21] for oyster larvae collected at Paranagua Estuarine Complex, which is known by its higher water temperatures.

Studies conducted with $C$. rhizophorae and C. brasiliana in several coastal areas in Northeastern, Southeastern and Southern Brazil have suggested oyster reproduction all year long; spawning takes place in the hottest times of the year [22,23,24,5]. Food availability and salinity can also affect gametogenesis, as well as larval duration and distribution in the plankton [25]. Guaratuba Bay presents phytoplankton any time of the year, mainly in summer, when nutrient availability and high temperatures contribute to its development [27].

In addition to the parameters mentioned above, the dispersion mechanism and larval retention in estuarine environments have suggested interaction among local conditions, water circulation and larval behavior [14]. Studies conducted with $C$. virginica have found unequal larval distribution in estuaries due to currents and tides [27]. Estuaries are influenced by tides, current speed and freshwater contribution; these factors, as well as planktonic larvae transport and survival, determine the distribution and density of adult oyster populations [27]. However, adult oyster population renewal can be compromised if larvae are transported to inappropriate areas for settling and metamorphosis [28]. The high larval concentrations in the bay's inner sector makes a large number of larvae return for settling in natural oyster banks purposes. Similar behavior was observed by $[26,5]$ in oyster larvae found in the Paranaguá Estuarine Complex. In addition, the conspicuous bedding attributed to the bay's geomorphology - which presents a narrow and deep channel at its entrance and a shallow inner region - and to its water - residence time can contribute to larvae retention in the bay's internal sections. These data are in compliance with those observed for the recruitment $[29,15]$ and distribution of oyster banks in Guaratuba Bay $[30,31]$. 


\section{Larval distribution in the estuary}

Point III presented lower salinity values than Points I and II likely due to freshwater contribution (Supplementary material FS4). Point III recorded higher larval concentration than the other points. Such a concentration is likely related to lower salinity and to higher primary productivity [32]. A previous study has shown high oyster-seed recruitment rates at this same point, in the median region of the estuary [15]. There are natural banks of bottom oysters and stones close to Point III, they are exploited by riverine communities in the region $[30,31]$. Although this point was never monitored, it has shown more potential to recruit oyster seeds than the other points monitored in the region [29]. Sharp larval density decrease was recorded in February 2004 in this same point; this finding met the time-period presenting the lowest water transparency value $(0.50 \mathrm{~m})$. This outcome may be explained by the date scheduled for sample collection (February 09 , 2005), which took place right after an important Brazilian holiday. Point III (Garças Island) is very popular among tourists who sail small- and medium-sized boats, mainly at this time of the year. Disturbances, such as sediment suspension and water displacement caused by the circulation of high-speed boats, may have affected larval distribution throughout February. In addition, population increase in Guaratuba City during the holiday [32] may have contributed to increase urban-waste discharge in the watershed, at the bay's middle sector. This process may have affected larval density during sampling, since this condition was not observed in the other points (I and II).

Points I and II were located in the mouth of the bay; they showed lower larval density throughout the year (Supplementary material FS5A). Temperature, salinity, swell, current speed and tides were the environmental factors capable of determining horizontal larval displacement. Studies [26] conducted with oyster larvae in Paranaguá Estuarine Complex have suggested that individuals close to the settling stage adopt an active displacement mechanism to remain inside the estuary, where they find areas potentially favorable to recruitment [14,15]. The loss of larvae close to the mouth due to their exportation to the ocean is an important factor among these mechanisms [14]; it could be observed at Point I, where density was lower than in Point III, at the median sector of the estuary. A previous study has shown two simultaneous current nuclei in the mouth of the estuary, which are ruled by flux and reflux in this area [16]. In addition, lack of natural oyster banks explored after Point I (oceanic region) and the presence of natural oyster banks explored in the bay's inner part, close to Point III [30,31], point towards larvae loss.

Point II recorded the lowest larval density, similar to the finding observed in Guaratuba Bay [30]. Some authors also noticed the same condition for oyster recruits at this point [15]. This outcome could have been caused by competition between larvae and adult oysters. According to Mizerkowski and coauthors [32], crops can reduce phytoplankton availability in this point at Guaratuba Bay.

\section{Larval Season in the estuary}

Temporal larvae variation in the three Guaratuba Bay points revealed a difference between winter and other seasons, similarly to what was observed in other points monitored at the mouth of the bay, which have presented higher larval density in winter and summer [29]. The analysis of larval density conducted at the three sampled points on a monthly basis evidenced higher larval density in late spring (November 2003), summer and in early fall (March 2004). A previous study has described larval density peak in the opening mouth in November [28]. Another study [17] has confirmed the same pattern, but with winter recruitment different from that of other seasons. Larval density differences were observed in 9 of the 12 assessed months; Point III recorded the highest larval densities. Accordingly, there are differences between the two sectors in the bay (median and mouth) and at different times of the year. Thus, identifying the most promising time and place for allocating seed collectors is of paramount importance for ostreiculture advancement in this estuary, in the short-term, if ones take into consideration seed extraction without affecting natural oyster banks.

\section{CONCLUSION}

Based on the results recorded for larvae spatial distribution, spring and summer are the seasons evidencing the most expressive mean number of larvae. The largest larval concentration was observed at Point III, in the intermediate section of Guaratuba Bay. This sector would be promising for seed collection. Further studies focused on identifying the larval stages of oyster species in zooplankton are necessary in order to help developing low-cost methodologies for seeds' environmental monitoring and recruitment. Therefore, it's necessary to expand studies in this sector of the estuarine system to corroborate the 
potential availability of larvae for seed capture. These studies can help better understanding oyster larvae retention and dispersion processes in estuarine environments.

Funding: This research received no external funding.

Acknowledgments: The authors would like to thank Hamilton Kirchner, from "Restaurante Ostra Viva" for his support during the collections.

Conflicts of Interest: The authors declare no conflict of interest.

\section{REFERENCES}

1. Stenzel HP Oysters. In: Moore RC ed. Treatise on Invertebrate Paleontology Lavorence, Soc. Am/Univ. Kansas. 1971; 3(N): 953-1224.

2. Strathamann MN Reproduction and Development of Marine Invertebrates of the Northen Pacific Coast. University of Washinton Press, 1992;2:670p.

3. Thomas Y, Garen P, Bennett A, Le Pennec M, Clavier J. Multi-scale distribution and dynamics of bivalve larvae in a deep atoll lagoon (Ahe, French Polynesia). Marine Pollution Bull. 2012, 65: 453-62.

4. Ren JS, Ross AH, Schiel DR. Functional descriptions of feeding and energetics of the Pacific oyster Crassostrea gigas in New Zealand. Mar. Ecol. Prog. Ser. 2003, 208: 119-30.

5. Christo SW, Ferreira SL, Absher TM, Ferreira-Jr AL. Ocorrência de larvas pedivéliger de ostras do gênero Crassostrea sacco, 1897 no setor euhalino do Complexo Estuarino de Paranaguá - PR. Publicatio, 2013;19(2): 85-91.

6. Liang X, Fang J, Tang Q, Jiang W, Peng S, Ji Y. Studies on prevention of the fouding oyster larvae from attaching to cultured bay scallop (Argopecten irradians Lamark) in Jincheng cultivation area of Laizhou Bay. Mar Fish. Res. 2000; 21(1): 27-30.

7. Orban E, Lena G, Masci M, Nevigato T, Casini I, Caproli R, Gambelli L, Pellizato M. Growth,nutricional quality and safety of oysters (Crassostrea gigas) cultured in the Lagoon of Vence (Italy). J. Sci. Food. Agric. 2004;84(14):1929-38.

8. Mileikowsky SA. Speed of active movement of pelagic larvae of marine invertebrates and they ability to regulate their vertical position. Mar. Biol. Berlim. 1973;23:11-7.

9. Selinger HH, Boggs JA, Biggley WH, Aspden K.H. The transport of oyster larvae in an estuary. Mar. Biol. 1982;71:57-72.

10. Mann R, Evans DA. Estimation of oyster, Crassostrea virginica, standing stock, larval production and advective loss in relation to observed recruitment in the James River, Virginia. J. Shellfish Res. 1998;17(1):239-53.

11. Campos BM, Luckenbach MW. Swimming rate and responses of larvae three mactrid bivalves to salinity discontinuities. Mar. Ecol. Prog. Ser. 1991;68:257-69.

12. Wood L, Harges-JR WJ. Transport of bivalve larvae in a tidal estuary. Proc. Eur. Mar. Biol. Symp.,1971;4: 29-44.

13. Baker P. Two species of oyster larvae show different depth distrubuitions in a shallow, well- mixed estuary. J. Shellfish Res. 2003;3(3):733-6.

14. Kern Y, Boehs G, Absher TM. Distribution of mollusc larvae in the estuarine complex of Paranaguá bay (Paraná, Brazil) (lat. $25^{\circ} 15^{\prime}-25^{\circ} 30$ 's). Publicatio, 2012; 18(1):15-23.

15. Christo SW, Ferreira-Jr AL, Cruz-Kaled AC, Absher TM. Recruitment of oysters of Crassostrea genus (Bivalvia, Ostreidae) in Guaratuba Bay, PR, Brazil. Pan-American Journal of Aquatic Sciences, 2016;11:301-308.

16. Christo SW. Biologia reprodutiva e ecologia de ostras do gênero Crassostrea Sacco, 1897 na Baía de Guaratuba (Paraná - Brasil): um subsídio ao cultivo. Tese de doutorado, Universidade Federal do Paraná, Departamento de Zoologia, 2006;137pp.

17. Marone E, Noernberg MA, Dos Santos I, Lautert LF, Andreoli OR, Buba H, Fill HD. Hydrodynamic of Guaratuba Bay, PR, Brazil. J. of Coastal Res. 2006;39:1879-1883.

18. Galvão MSN, Pereira OM, Machado IC, Henrique MB. Aspectos reprodutivos da ostra Crassostrea brasiliana de manguezais do estuário de Cananéia, SP (25ㅇ; 48W). B. Inst. Pesca. 2000;26(2):147-162.

19. Christo SW, Absher TM. Reproductive period of Crassostrea rhizophorae (GUILDING, 1828) and Crassostrea brasiliana (Lamark, 1819) (Bivalvia: ostreidae) in Guaratuba bay, Paraná, Brazil. J. of Coastal Res., 2006;SI 39: 1215-8.

20. Christo SW, Absher TM. Crescimento da prodissoconcha de ostras do gênero Crassostrea SACCO, 1897 (BIVALVAE: OSTREIDAE). B. Inst. Pesca. 2008;34(1):71-7.

21. Silva GB, Absher TM. Variação temporal de larvas de ostras do gênero Crassostrea SACCO, 1897 (Ostreoida:Ostreidae) na Baía de Paranaguá, Paraná. Arq. Biol. Tecnol. 1996;39(4):903-10. 
22. Nascimento IA, Lunetta JE. Ciclo sexual da ostra de mangue e sua importância para o cultivo. Bol. Fisiol. Animal, Universidade de São Paulo. 1978;2:63-8.

23. Akaboshi S, Bastos AA. El cultivo Del ostion Crassostrea brasiliana em la region lagunar de Cananéia, São Paulo, Brasil. In: Simposio sobre Aquicultura en América Latina, Roma, 1977;FAO p.232.

24. Gomes Cha M, Silva FC, Lopes GR, Melo CMR. The reproductive cycle of the oyster Crassostrea gasar Braz. J. Biol., 2014;74(4):967-76.

25. Boehs G, Absher TM. Distribuição de larvas de ostras do gênero Crassostrea SACCO, 1897. (OSTREOIDA: OSTREIDAE) na Baía de Paranaguá, Paraná. Arq. Biol. Tecnol. 1997;40(1):39-45.

26. Brandini N. Biogeoquímica da Baía de Guaratuba, Paraná, Brasil: Origem, metabolismo, balança de massa e destino biogênico. Tese de doutorado, Universidade Federal do Paraná, 2008;190pp.

27. Newell RIE, Alspach JRGS, Kennedy VS, Jacobs D. Mortality of newly metamorphosed oysters (Crassostrea virginica) in mesohaline Chesapeake Bay. Mar. Biol. 2000;136:665-76.

28. Southworth M, Mann R. Decadal scale changes in seasonal patterns of oyster recruitment in the Virginia sub estuaries of the Chesapeake Bay. J. Shellfish Res., 2003;23(1):312pp.

29. Neto RM, Ludwig TOZS, Horodesky A, Girotto, MVF Castilho-Westphal, G.G.; Ostrensky, A. Influence of environmental variables on the growth and reproductive cycle of Crassostrea (Mollusca, Bivalvia) in Guaratuba Bay, Brazil. Invert. Reprod. \& Dev., 2012; 57(3): 208-18.

30. Castilho-Westphal GG, Dal Pont G, Horodesky A, Ostrensky A. Comunidades ribeirinhas extrativistas e a exploração de bancos de ostras do mangue Crassostrea sp., na baía de Guaratuba - Paraná, litoral sul do Brasil. Biosci. J., 2014;30(2):912-23.

31. Castilho-Westphal GG, Ostrensky A. Use of side-scan sonar for estimations of Crassostrea brasiliana (Lamarck, 1819) stocks in subtidal banks on the south coast of Brazil. Braz. J. Ocean., 64(1):49-56.

32. Mizerkowski BD, Machado EC, Brandini N, Nazario MG, Bonfim KV. Environmental water quality assessment in Guaratuba bay, state of Paraná, Southern Brazil. Braz. J. Ocean. 2012;60(2):109-15.

(C) 2021 by the authors. Submitted for possible open access publication under the terms and conditions of the Creative Commons Attribution (CC BY NC) license (https://creativecommons.org/licenses/by-nc/4.0/). 